International Journal of Library \& Information Science (IJLIS)

Volume 7, Issue 4, July-Aug 2018, pp. 1-9, Article ID: IJLIS_07_04_001

Available online at

http://iaeme.com/Home/issue/IJLIS?Volume=7\&Issue $=4$

Journal Impact Factor (2016): 8.2651 (Calculated by GISI) www.jifactor.com

ISSN Print: 2277-3533 and ISSN Online: 2277-3584

\title{
STATUS OF LIBRARY AUTOMATION AND ICT INFRASTRUCTURE IN PRIVATE AIDED FIRST GRADE COLLEGE LIBRARIES IN BANGALORE CITY
}

\author{
Santosh Kumar S.K \\ Research Scholar and Librarian, Government First Grade College, \\ Nelamangala, Bangalore Rural District Karnataka State \\ Dr. Chandrappa. S \\ Research Guide and Vice Chancellor, Kalinga University, Raipur, \\ Chhattisghar, India
}

\begin{abstract}
Purpose: The intention of this research paper is to study the status of Library Automation in 23 Private Aided First Grade Colleges in Bangalore City, by collecting data on Library Automation, Library Management Software being used, availability of ICT infrastructure and concern problems.

Methodology: A Structured questionnaire, observation and interview were used as tools for the data collection from selected

Findings: Majority of the Private Aided First Grade Colleges are undergone NAAC accreditation and accredited colleges are automated using licensed software. Majority of the college libraries are facing the difficulties in lack of funds, skilled staff, and infrastructure.
\end{abstract}

Originality / Value - This study was conducted on Government First Grade College Libraries in Bangalore City but none have surveyed the status of library automation and ICTs in Private aided Colleges in Bangalore Cit. This paper provides statistical data on current status of library automation, types of Library Management software used and its ICTs infrastructure availability. This study also provides statistical data on current status of library automation, type of library software used.

Key word: Higher Education, Library Services, Library Automation, College Library, ICTs.

Cite this Article: Santosh Kumar S.K and Dr. Chandrappa. S, Status of Library Automation and ICT Infrastructure In Private Aided First Grade College Libraries In Bangalore City. International Journal of Library \& Information Science, 7(4), 2018, pp. 1-9.

http://iaeme.com/Home/issue/IJLIS?Volume=7\&Issue $=4$ 


\section{INTRODUCTION}

Library is one of the major pillars in the Higher Education Institutions. It is gaining very importance in Digital Era, where without much time users are accessing information and staff through Library automation, the housekeeping services are very speedy and reliable. Now a day each and every field we are using computer starting from Library services to travel around the world. In Bangalore City there are 44 private aided FirstGradeColleges established with the aim of empower the students, the role of libraries and Librarians in private aided Colleges is to adopt ICT and automation, this has become essential for many reasons: large number of student and faculty members are utilize library information at same time it is most challenging job to Librarians to implement the Library automation system in private aided degree Colleges. These Colleges are facing lack of funds, manpower, training and motivation, delay to implementation. This paper discusses several queries on the present status of automation application in the FirstGradeCollege libraries and libraries of Private Aided Institutions.

\section{LIBRARY AUTOMATION}

The term "library automation" refers to the phenomenon of mechanization of traditional library activities, such as acquisition, serial control, cataloguing and circulation control etc. Today the term "library automation" is however used extensively to refer primarily to the use of computers to perform the library activities in recent times. "Library Automation" is generally defined as the replacement of manual operations in libraries by computerized methods. Started in late 1970s in few special libraries it has now reached most of all kinds of libraries. Over the past three decades, libraries have changed considerably as bibliographic utilities, online catalogues; automated circulation systems and other new technologies have been implemented in majority of library operations and services.

\section{ICT AND LIBRARY AUTOMATION IN PRIVATAIDEDFIRSTGRADECOLLEGE IN BANGALORE CITY}

ICTs play tremendous Library automation and provide right information at right time to the needy. Here the libraries of private aided First Grade Colleges in the Bangalore City need to be versatile to meet the its large students and faculty to empower the Indian education system. So that libraries librarian need to be automated its housekeeping services and add Information Technology based service for effective use of library facilities by College faculties and students. Computerization not only ease out the job of librarians who single handedly manage library activities without assistant librarians and Library assistants and library support staff, it also helps library in providing better services to College faculties and students. It is also mandatory for any College for undergoing NAAC accreditation/ re-accreditation. Keeping in the mind of these points, the study highlights the library automation as an importance of this paper.

\section{OBJECTIVES OF STUDY}

The objectives of the study are:

- To identify the current status of library automation in Private aided College of Bangalore city.

- To find out the library Management software used for automation of libraries.

- To know library automation infrastructure of these College libraries.

- To study the library automation software's used by these College libraries.

- To study the ICTs skills and problems faced by the library staff.

- To know satisfactory level of users in the automation system of services. 


\section{REVIEW OF RELATED LITERATURE}

The research carried Private aided FirstGradeCollegelibraries can help to understand the role of ICT and automation to make informative skills in users of these Colleges. A lot of work has been published in the field of library automation in previous years, many of the authors are suggested in for the automation as a focal point in various libraries studies in different locations in world, keeping this in mind researcher attempted to study the library automation conditions in Bangalore city particularly in Private aided College libraries. The following the review literature which forced to carry this study.

Jayamma K V \& Krishnamurthy M (2015) The study was observed that majority of Bangalore Government First Grade College libraries have automated partially and all libraries managed by single librarian

Naveen C.L and Nagesh R(2016) some of the libraries fully automated, some libraries partially and some initiated due to lack of fund and staff most of all College libraries using open free library software and also facing problems by lack infrastructure, skilled staff and funds to implement the fully automation of library and its services.

Takappa R and K Ramakrishna Reddy (2017) survey says Private Polytechnic Libraries are in better position when compare to Aided and Government Polytechnic Libraries. The existing status of computer hardware and its peripherals in the Polytechnic Libraries is not satisfactory. Barriers such as insufficient funds, lack of trained staff, and lack of infrastructure are faced by a majority of the libraries.

\section{METHODOLOGY}

The Methodology adopted for collecting the required data from the Librarians of Private Aided College Libraries are firstly the addresses of Private aided College in Bangalore city were collected through formal sources that on Department of Collegiate Education Website www.dce.kar.nic.in. This study is based on a structured questionnaire was used as a tool for the data collection. Researcher by personally meant the librarian's circulated the questionnaire and also researcher has been observed personally the libraries and it stock, services etc... perused some of the observation and recorded in analysis.

\section{SCOPE AND LIMITATIONS}

A huge number of Higher Education Institutions exist, with various disciplines. Among these First Grade Colleges plays important role in imparting education to the students who completed $10+2$ standard. This study is limited to Private Aided First Grade College, at present there are 44 Private Aided First Grade Colleges in Bangalore City, only 30 College libraries were considered for the present study.

\section{ANALYSIS AND INTERPRETATION}

The data collected by questionnaire and observation methods, were analyzed and interpreted by simple percentage method and same as depicted in tables.

\subsection{Distribution of Questionnaires and the Response rate}

Researcher has been selected 30 Private Aided First Grade Colleges for the study, and circulated the structured questionnaire to these Colleges, to identify the library automation status. 
Table 1 Rate of Response by Librarians

\begin{tabular}{|c|c|}
\hline No. of Questionnaires distributed & $\mathbf{3 0}$ \\
\hline Response Rate & $23(76.67 \%)$ \\
\hline Not respondent & $07(23.33 \%)$ \\
\hline
\end{tabular}

The table 1 shows that, 30 Private Aided First Grade College were selected for the study in Bangalore city. Out of these 23(76.66\%) College libraries were responded to the questionnaires remaining $7(23.33 \%)$ Colleges not returned the questionnaire after repeated communication, it shows that due to their work constrains, non-availability of the ICTs these college librarians might not returned the questionnaires.

\subsection{Status of NAAC Accreditation}

National Accreditation and Assessment Council of India made compulsory for libraries to adapt the automation system to its housekeeping service and function for opt the accreditation of its institution

Table 2 Status of NAAC Accreditation

\begin{tabular}{|l|c|c|}
\hline \multicolumn{1}{|c|}{ Status } & $\begin{array}{c}\text { No of } \\
\text { College }\end{array}$ & $\begin{array}{c}\text { Percentage } \\
(\boldsymbol{\%})\end{array}$ \\
\hline Accreditation & 21 & 91.30 \\
\hline Non- Accreditation & 2 & 8.70 \\
\hline Total Colleges & 23 & 100.00 \\
\hline
\end{tabular}

Table 02 depicts that, out of 23 College libraries 21 (91.30\%) were accredited from NAAC with different Grades. $02(8.70 \%)$ colleges not accredited. This study stipulates that the Library Automation is mandatory for the NAAC Process, due to this the accredited colleges might be automated their housekeeping services.

\subsection{Status of Library Automation}

Library Automation is very necessary for almost of the libraries to provide serves with least time to its users. There are number of Library Management System Software's available in the market. Let see how many of the college Libraries $(\mathrm{N}-23)$ are under the automation system.

Table 3 Status of Library Automation

\begin{tabular}{|l|c|c|c|}
\hline \multicolumn{1}{|c|}{$\begin{array}{c}\text { Status } \\
\text { Automation }\end{array}$} & \multicolumn{2}{|c|}{$\begin{array}{c}\text { Yes } \\
\mathbf{2 1}(\mathbf{9 1 . 3 0 \% )}\end{array}$} & $\begin{array}{c}\text { No } \\
\mathbf{2 ( 8 . 7 0 \% )}\end{array}$ \\
\hline $\begin{array}{l}\text { Fully } \\
\text { Automated }\end{array}$ & 14 & $60.86 \%$ & \\
\cline { 1 - 2 } $\begin{array}{l}\text { Partially } \\
\text { Automated }\end{array}$ & 7 & $30.43 \%$ & \\
\cline { 1 - 2 } In Progress & 0 & $0.00 \%$ & \\
\cline { 1 - 2 } Planned & 2 & $8.70 \%$ & \\
\cline { 1 - 2 } & &
\end{tabular}

Table 3 stipulated that out of 21(91.30\%) Automated Libraries 14 (60.86\%) Libraries are fully Automated and 7 (30.43\%) Libraries are partially automated due to lack of confidence on ICTs infrastructure for instance power supply, software problems, funds and skilled staff. 
Status of Library Automation and ICT Infrastructure In Private Aided First Grade College Libraries In Bangalore City

\subsection{Library Automation Software}

The Colleges selected for studies were used four different types of library automation software and the details are presented below.

Table 4 Library Management System Software's

\begin{tabular}{|c|c|c|c|}
\hline $\begin{array}{c}\text { Library } \\
\text { Software }\end{array}$ & Mode of permit & $\begin{array}{c}\text { Total Colleges } \\
\mathbf{N - 2 3}\end{array}$ & $\begin{array}{c}\text { Percentage } \\
(\mathbf{\%})\end{array}$ \\
\hline EasyLib & Purchase & 12 & 52.17 \\
\hline E-granthalaya & Open Source & 1 & 4.35 \\
\hline Libsoft & Purchase & 7 & 30.43 \\
\hline New Genlib & $\begin{array}{c}\text { Free } \\
\text { \&Maintenance }\end{array}$ & 1 & 4.35 \\
\hline
\end{tabular}

Table shows that $12(52.17 \%)$ of respondents are using EasyLib automation software, purchased, 7 (30.43\%) are using Libsoft software it is also purchased. 1 (4.35\%) respondents are using E-granthalaya and NewGenLib the open source software respectively. It depicts that the selection of software of automation is more libraries by the purchase, they think that licensed one is better for their college because software organization are providing services whenever any problems goes with the automation software's. The service from the software provider is much more important, as all librarians are not skilled in the programming language.

\subsection{ICTs Infrastructure available in Private Aided First Grade College Libraries}

ICTs Infrastructure is prime resource to adopt the automated services and online resources accessibility and provide the same to the user community of their discipline. Researcher made an attempt to depict the ICTs infrastructure availability in Private Aided First Grade College libraries for the Library Automation and create online information services in their respective libraries.

Table 5 ICTs infrastructure availability

\begin{tabular}{|l|c|c|}
\hline \multicolumn{1}{|c|}{ Description } & No of Respondents & Percentage (\%) \\
\hline Air Conditioning & 2 & 8.70 \\
\hline Barcode Printer & 20 & 86.96 \\
\hline Barcode Reader & 21 & 91.30 \\
\hline CCTV & 18 & 78.26 \\
\hline Computer & 23 & 100.00 \\
\hline LCD Projector & 8 & 34.78 \\
\hline Photocopy Machine & 19 & 82.61 \\
\hline Printer & 23 & 100.00 \\
\hline Scanner & 22 & 95.65 \\
\hline Server & 19 & 82.61 \\
\hline UPS & 22 & 95.65 \\
\hline Vacuum Cleaner & 15 & 65.22 \\
\hline Web Camera & 4 & 17.39 \\
\hline
\end{tabular}

Table 5 says that the ICTs infrastructure availability in the selected college for the study, $23(100 \%)$ all the college have Computer terminals and printer irrespective of its number, 22 (95.65\%) respondents have Printers and UPS, 21 (91.30\%) respondents have Barcode 
Readers, $20(86.96 \%)$ respondents have Barcode Printers, $20(82.61 \%)$ respondents have Photocopy Machine and Servers, 18 (78.26\%) respondents have CCTV for the vigilance over the theft. A good number of the libraries are well equipped with ICTs infrastructure and about computer systems, only two of them have to automate their library services. As they are in planning stage in span of time, these two colleges also will be automating their library systems in future.

\subsection{Orientation/training on ICTs in Library}

Library Staff of any Library in Higher Education play significant role in imparting the information changing needs of its users. Library staff badly needs orientation/training on ICTs for automation of their libraries and provide online resources, here the researcher has attempted to describe the ICTs skills among the selected libraries library staff for the study

Table 6 Orientation/training on ICTs in Library

\begin{tabular}{|c|c|c|}
\hline Using ICTs & $\begin{array}{c}\text { No of Staff are trained in } \\
\text { ICTs }\end{array}$ & Percentage (\%) \\
\hline Yes & 18 & 78.26 \\
\hline No & 5 & 21.74 \\
\hline
\end{tabular}

Table 6 shows that, 18(78.26\%) College library staffs have undergone orientation on using ICTs and 5(2.74\%) respondents were learnt by ICTs themselves. It shows that the proper tanning should be provided when the ICTs changes.

\subsection{Internet Accessibility}

Internet connectivity is the prime element for accessing information resources, now a day it become life blood of human being for every aspect of his activities, the information needs of the users are drastically changing Librarians should have Internet connection to provide changing and latest needs to its users.

Table 7 Internet Accessibility in college Libraries

\begin{tabular}{|c|c|c|}
\hline Type & $\begin{array}{c}\text { No of } \\
\text { Colleges }\end{array}$ & $\begin{array}{c}\text { Percentage } \\
(\boldsymbol{\%})\end{array}$ \\
\hline Internet Connection & 21 & 91.30 \\
\hline Non-Internet Connection & 2 & 8.70 \\
\hline
\end{tabular}

Table 7 furnishes that $21(91.30 \%)$ respondent libraries have Internet connection for access online resources and other communication. Only $2(8.70 \%)$ respondent libraries are yet to plan for the Internet Connection.

\subsection{Networking and Consortia for Resource Sharing}

Networking and Consortia's are need for the day, because of high cost of e-resource and low budgets for these college libraries. Networking and Consortia's are providing largest number of e-journals and e-books to its members through license.

Table 8 Networking and Consortia for Resource Sharing

\begin{tabular}{|c|c|}
\hline Type & Percentage \% \\
\hline Member of NLIST & $21(91.30 \%)$ \\
\hline Non-Member & $2(8.70 \%)$ \\
\hline
\end{tabular}


Status of Library Automation and ICT Infrastructure In Private Aided First Grade College Libraries In Bangalore City

Table 8 shows that, $21(91.30 \%)$ of respondent libraries are actively participating in Networking and consortia for resource sharing as these Colleges were accredited by the NAAC the cost of the NLIST is low and 2(8.70\%) respondents are not members of any consortium because cost of the membership is high compared with accredited college libraries membership fee.

\subsection{Library Website}

Website plays a significant role in providing some of library services and its notification off the campus. Most of the users are benefited from Library website attached with OPAC facility to save their time.

Table 9 Library Website

\begin{tabular}{|c|c|c|c|}
\hline Respondents & $\begin{array}{c}\text { Percentage } \\
(\boldsymbol{\%})\end{array}$ & Mode of Operation & $\begin{array}{c}\text { Percentage } \\
(\mathbf{\%})\end{array}$ \\
\hline Yes & $17(73.91)$ & Independent Website & $3(17.65)$ \\
\hline No & $6(26.09)$ & Through College Website & $14(82.35)$ \\
\hline
\end{tabular}

Table 9 depicts that 17 (73.91\%) college libraries have website in two modes of operation, out of this $3(17.65 \%)$ had independent website for the library and $14(82.35 \%)$ were working through their college website for providing library services and its notification.

\subsection{Satisfaction of libraries in their services to users}

Automation and ICTs Adoption made Services improved in the Private Aided College Libraries of Bangalore City. Majority of them are utilizing the benefits of the ICTs and job of the library staff also made easy today by the advent of ICTs.

Table 10 Satisfaction level of Libraries in providing services

\begin{tabular}{|c|c|}
\hline Services by ICTs & Percentage (\%) \\
\hline Improved & $21(91.30)$ \\
\hline Not Improved & $2(8.70)$ \\
\hline
\end{tabular}

Table 10 highlights that $21(91.30 \%)$ of respondents are have satisfied by the imparting services thorough Automation and ICTs. $2(8.70 \%)$ of the respondents are still in the planning level. It shows the users and library staff are satisfied because of automation the time has been saved.

\subsection{Difficulties Faced in Library Automation and ICTs adoption}

The difficulties faced by the Librarians in library Automation and adoption of ICTs are tabulated below:

Table 11 Difficulties faced by the Libraries in Library Automation and ICTs adoption

\begin{tabular}{|l|c|c|}
\hline \multicolumn{1}{|c|}{ Difficulties } & Yes & No \\
\hline Lack of Support for Institution & $2(8.70 \%)$ & $21(91.30 \%)$ \\
\hline Lack of Support for Library Advisory Committee & $2(8.70 \%)$ & $21(91.30 \%)$ \\
\hline Insufficient Staff & $16(69.57 \%)$ & $7(30.43 \%)$ \\
\hline Lack of Interest in Library Staff & $9(39.13 \%)$ & $14(60.87 \%)$ \\
\hline Lack of Trained Library Staff & $16(69.57 \%)$ & $7(30.43 \%)$ \\
\hline Lack of Infrastructure & $11(47.83 \%)$ & $12(52.17 \%)$ \\
\hline Lack of Funds & $15(65.22 \%)$ & $8(34.78 \%)$ \\
\hline
\end{tabular}


Table 11 depicts the difficulties faced by the librarians in library automation process in Private Aided First Grade College Libraries in Bangalore City are Lack of support from Institution, Library Advisory Committee, the major difficulties are Lack of staff, interest in staff, trained library staff and funds are faced by many libraries.

\section{FINDINGS}

The following findings and conclusions were drawn based on the analysis of data.

- Most of the colleges are undergone NAAC Accreditation and these all Accredited college libraries that is $21(91.30 \%)$ are automated its services, out of which $14(60.86 \%)$ Libraries are fully Automated and $7(30.43 \%)$ Libraries are partially automated due to lack of funds and staff.

- Among automated libraries $12(52.17 \%)$ and 7 (30.43\%) of respondents are using EasyLib and Libsoft purchased software, 1 (4.35\%) respondents are using E-granthalaya and NewGenLib the open source software respectively.

- A good number of the libraries are well equipped with ICTs infrastructure and about computer systems, only two of them have to automate their library services, as they are in planning stage in span of time these two colleges also will have automated library systems.

- $21(91.30 \%)$ of respondent libraries have Internet Connection, Member of NLIST Consortia and Satisfaction of librarians in their services is also at good existent.

- $17(73.91 \%)$ college libraries have website for providing library services and notification.

- $16(69.57 \%)$ of respondents are facing difficulties like Lack of trained and insufficient staff and lack of funds and infrastructure.

\section{SUGGESTIONS}

1. Parent institutions should provide sufficient funds as per the norms given by Dr. S. R Ranganathan (1965) or by Kothari Commission (Gupta, 1992) to procure infrastructure and Electronic information resources.

2. Staff of the library should be sent to training courses to upgrade their IT skills and appoint required staff according to Dr. S. R. Ranganathan's Staff formula.

3. Library staff should have their own Library website rather than attested with College Website, for providing better services.

4. Library Staff should be sent to the training, workshops on Institutional Repositories software to build their own repositories.

5. The libraries which partially automated libraries have to be fully automated in future for saving the time of staff and users of the library.

\section{CONCLUSION}

The Library Automation and ICTs services are important in the Digital Environment, as and when changes take place in the ICTs radically the library environment also changes because to meet the user's needs as they are speculative in nature. The Private Aided First Grade College Libraries in Bangalore City are well equipped with ICTs infrastructure and have purchased automation Software for the automation of its services and function. Yet to develop in the digital environment only three college libraries have their own website and their staff as to increased and trained as and when the new technologies come to existence. 
Status of Library Automation and ICT Infrastructure In Private Aided First Grade College Libraries In Bangalore City

\section{REFERENCES}

[1] Jayamma, K. V\& Krishnamurthy. M. Automation of College Libraries in Bangalore City: A Study. International Journal of Advanced Research in Computer Science and Management Studies, 2015, 3(9), 32-40.

[2] Takappa, R \& Ramakrishna Reddy, K. Present Status of Library Automation in Polytechnic Colleges in Karnataka State: A Survey. International Journal of Digital Library Services, 2017, 7(2), 87-98.

[3] Otunla, AderonkeOlufemi. Current Status of Automation in Academic Libraries in Osun State, Nigeria. Journal of Applied Information Science and Technology, 2016, 9(2), 2939.

[4] Upadhyay, Ashutosh; Pandey, Varsha \& Shrivastava, B.P. A Review of Status, Problem and Prospects of Library Automation in Engineering Colleges of Jabalpur City, IOSR Journal of Computer Engineering, 2012, 3(5), 31-36.

[5] Naveen, C.L \& Nagesh, R. Status and Problems of Library Automation in Govt. First Grade Colleges of Hassan District, Karnataka: A Study, International Journal of Library \& Information Science, 2016, 5(1), 28-35. 